\title{
Film Subtitles as a Successful Vocabulary Learning Tool
}

\author{
Catherine Kanellopoulou \\ Department of Audio \& Visual Arts, Ionian University, Corfu, Greece \\ Email: catherine.kanellopoulou@gmail.com
}

How to cite this paper: Kanellopoulou, C. (2019). Film Subtitles as a Successful Vocabulary Learning Tool. Open Journal of Modern Linguistics, 9, 145-152.

https://doi.org/10.4236/ojml.2019.92014

Received: January 17, 2019

Accepted: April 27, 2019

Published: April 30, 2019

Copyright $\odot 2019$ by author(s) and Scientific Research Publishing Inc. This work is licensed under the Creative Commons Attribution International License (CC BY 4.0).

http://creativecommons.org/licenses/by/4.0/

\begin{abstract}
Films are a valuable source of authentic language material, but what makes them superior to other types of authentic materials is the existence of a full storyline which leads to the increased engagement of the viewer. Despite the fact that teachers intuitively know this particular activity which may enhance language learning there is little research that has sought to thoroughly examine its potential impact on vocabulary acquisition and retention. While most studies conclude that the type of subtitling is an important factor influencing vocabulary learning; defining which particular type of subtitling is most effective seems difficult to determine and results in this area are somewhat inconclusive. Further research is, therefore, necessary to determine which type of subtitling would lead to optimum results in vocabulary acquisition and retention.
\end{abstract}

\section{Keywords}

Authentic Materials, Film, Subtitling, Vocabulary Retention, Vocabulary Acquisition, Engagement, Subtitling Types

\section{Authenticity in the Language Classroom}

The success of a training program, in the case of learning a foreign language, depends on the classroom atmosphere and the pedagogical materials used. As an educator, over years of student training, the need for materials that would attract students' attention has become clear to me; as well as the need to create an engaging environment for my class. In my experience, authentic materials, and films in particular, have had the best results in language teaching, and more particularly vocabulary long term acquisition. This triggered my interest in films and subtitling is as a vocabulary learning/teaching tool.

Nunan (1999) emphasizes that authentic linguistic material, whether spoken or written, is the one not created for the purpose of teaching, and further em- 
phasizes that sources of spoken authentic linguistic material can include television programs such as news, talks, songs, cartoons and films (Miller, 2003). In this paper, I have adopted Nunan's definition of authenticity, although the notion of authenticity is somewhat more complex and would require further investigation.

Apart from the authenticity of the linguistic materials, Taylor (1994) identified another two types of authenticity: authenticity of task and of authenticity of situation and he argues that these three types are not clearly distinguished.

Task authenticity reflects the purpose which language input serves; meaning that the chosen tasks should involve the learners not only in authentic communication with texts and others in the classroom, but also in the purpose of learning (Breen, 1985).

Authenticity of situation, on the other hand, is among the most challenging aspects of authenticity for classroom teachers to provide to their students (Beatty, 2015). Taking the example of a visit to a science museum where students would walk around the rooms, explore and often perform hands-on tasks relevant to the museum exhibits, and then report back in class on their experience, students learn by actively engaging themselves in a real life task. In this case, students would also learn related skills such as critical thinking, problem solving, scientific observation, note taking, writing, presentation techniques, and public speaking (Beatty, 2015). This can be contrasted to a an online search of the museum web pages in the language classroom or at home, where the approach is more theoretical, even though it does has an aspect of authenticity from the perspective of using the internet for gathering information.

Authentic tasks are not the norm in schools and classrooms, but research and contemporary perspectives on how students learn suggest that these types of tasks are powerfully effective for learning (Harris \& Marx, 2009). Requiring students simply to carry out a task will not ensure learning. Classroom tasks result in the acquisition of information that is not very meaningful, memorable, or usable. Psychologist David Perkins (1993) calls such information, which often results from rote memorizing and is not easily transferred to other situations, inert knowledge. For meaningful learning to occur, students need to be cognitively engaged, or intellectually invested, and active in applying ideas (Harris \& Marx, 2009).

As expected, there is controversy over the issue of the level at which authentic materials should be introduced in the classroom. Some researchers claim that authentic materials can be used with intermediate and advanced level students only (Kim, 2000; Kilickaya, 2004), whereas others believe that all ability levels of students, even lower levels, are able to manage using authentic materials (McNeill, 1994; Miller, 2005). What is of the essence is that authentic materials must be used in accordance with students' ability (Baird \& Redmond, 2004).

\section{Film Extracts Used in the Language Classroom as Source of Authentic Material}

Films are a valuable source of authentic material and belong to a vast array of 
similarly featured materials such as TV ads, news items, weather forecasts, radio talks, etc. (Hedge, 2000; Baird \& Redmond, 2004). What makes films superior to those other types of authentic materials is the existence of a full storyline that is non-existence, for example, in a weather forecast, or very limited in a news item. A storyline most often leads to the engagement of the viewer as they indirectly participate in the action of what they are watching. Another significant factor is the enjoyment of the viewer/student which plays a major role.

Then, what are the advantages or disadvantages of using films in the EFL classroom? Most of the following for and against arguments are true for all authentic materials, but I will focus on films. Films first and foremost offer authentic language input and cultural information in an easily digestible manner. They have a positive effect on learner motivation as the visual input enhances learners' understanding. They support a more creative approach to teaching and offer a huge variety of situations which inevitably leads to a higher chance that those situations will relate more closely to learners' needs and interests. Language styles are also varied and in general language and cultural input is continuously updated. Last but not least, the learner's satisfaction is a strong component which has a positive effect on comprehension (Kilickaya, 2004; Mcknight, 1995; Berardo, 2006; Wong et al., 1995).

On the other hand, there are some strong arguments against the use of films in the classroom, at least where these are used as a significant part of the language course. Films may be too culturally biased, to begin with. They often contain difficult language, vocabulary items that are beyond the scope of a particular lesson and complex language structures, which may cause a burden for the teacher in lower-level classes and might demotivate weaker students. Many structures are mixed and students might have a hard time decoding them and time is limited for this decoding as the film rolls on. Preparing such materials for the classroom can also be quite time consuming for teachers, who might need to present their students with pre-activities, especially in lower level classes. Authentic materials, including films, may not expose students to comprehensible input at the earliest stages of acquisition (Guariento \& Morley, 2001; Martinez, 2002; Kim, 2000).

In view of the above, careful selection and preparation of film extracts for classroom use is required. Most important factors in this selection are the suitability of the content, depending on the learners, the compatibility with the course objectives at each time and how easily the content can be exploited by the teacher to offer maximum learning results (Lee, 1995). Recent research supports the effectiveness of combining audio and visual aids in language classrooms. Visual input combined with other technology tools stimulates deeper comprehension of the texts and enhances the interaction between the target language and learners' mind which in turn, allows learners to predict the target language more easily and to recall more fully (Stevens, 1989; Underwood, 1990). One important feature of films that has emerged because of the advancements in video 
technology, and is a critical factor towards optimum exploitability of the material, is subtitling. A feature very little utilised in the classroom so far, which however could become a successful tool to combat some of the difficulties in adopting films as study material.

\section{Subtitling in Films and Its Effectiveness in Language Learning}

Watching films with subtitles is popular among language learners; however, this does not often constitute part of a language course. Despite the fact that teachers intuitively know this particular activity may enhance language learning, especially direct or incidental vocabulary acquisition, there is little research that has sought to thoroughly examine its potential impact on vocabulary uptake and retention (Garnier, 2014). Subtitled films can ensure a rich comprehensible input because of providing aural, visual and textual input (Zanon, 2006). In vocabulary learning, visual information can be crucial as it serves body language, gestures, facial expressions that accompany the meaning, intonation and stress of the vocabulary, as well as the culture and authentic language of the speakers (Aydin Yildiz, 2017). It should be noted here that subtitles added to a visual channel will neither distract nor interfere with the oral and pictorial information. Multiple resources of message can expand the capacity of working memory and effectively promote learning achievements.

Turning to the available types of subtitling, Zanon (2007) categorizes it into three types:

1) standard subtitling (L2 audio and L1 captions),

2) bimodal subtitling (L2 audio with L2 captions), and

3) reversed subtitling (L1 audio with L2 captions).

Whereas Katchen, Fox, Lin and Chun (2001) identify three more types of subtitling:

4) bilingual subtitling (L2 audio with L2 and L1 subtitles simultaneously),

5) bilingual reversed subtitling (L1 audio with L1 and L2 subtitles simultaneously),

6) no subtitling (L2 audio with no subtitles at all).

Most research to date has looked into the first three types of subtitling for establishing its effectiveness in language learning. While most studies conclude that the type of subtitling is an important factor influencing vocabulary learning (Gorjian, 2014) and developing listening skills (Kusumarasdyati, 2005), defining which particular type of subtitling is most effective seems difficult to determine and results in this area are somewhat inconclusive.

Among the different types of subtitling, most research points to the bimodal one, also called intra-lingual, as more common (Zanon, 2007) in classroom activities and more effective than the other types. Zanon (2007) also contends that text in the form of subtitles helps learners monitor a speech that would probably be lost otherwise. In fact, while TV programs and films that are not subtitled can 
create a high level of insecurity and anxiety in students, the incorporation of subtitles provides instant feedback and a positive reinforcement that contributes to create a feeling of confidence in learners and can help them feel ready and motivated to watch foreign films. It can also make tasks more manageable and user-friendly for weaker students. Baltova (2006) argued, on the basis of empirical evidence, that bimodal video which is subtitled in L2 is an effective way of enhancing L2 learners' understanding of authentic texts and learning of vocabulary because of the simultaneous exposure of the learner to spoken language, printed text, and visual information, all conveying the same message. Borras and Lafayette (1994) state that bimodal subtitling may help the second language learner associate the aural and written forms of words more easily and quickly than video without subtitles. In the same vein, Guichon and McLornan (2008) found that L2 subtitling (bimodal subtitling) was more beneficial than L1 because it caused less lexical interference. Zarei's (2009) result analysis showed that bimodal subtitling was significantly more effective than standard subtitling, which in turn, was significantly more effective than reversed subtitling. Similarly, the study of Fazilatfar, Ghorbani and Samavarchi (2011) as well as that of Zarei (2009) indicate bimodal subtitling as the most effective when regarding vocabulary recall, while reversed subtitling the least effective of the three. In Aydin Yildiz's (2017) experiment with 60 Turkish EFL intermediate students, the bimodal subtitling group performed better in the acquisition of vocabulary.

There is, however, a limited number of studies that favour reversed subtitling for the language classroom. Danan's study found that reversed subtitling was the most beneficial method for enhancing foreign language learning when compared to no-subtitling and standard subtitling (Danan, 2006) but in this case bimodal subtitling was not studied. In Gorjian's study, the participants in the reversed subtitling group performed significantly different and learned more new vocabulary items. Standard subtitling was found to be the second type of subtitling which revealed to be more effective than bimodal subtitling (Gorjian, 2014). And some studies (Karakaş \& Sariçoban, 2012; Yüksel \& Tanrıverdi, 2009), including the Turkish L2 learners of English as the participant group, did not reveal any significant difference between the groups, so those concluded that watching the movie clips facilitated the development of the vocabulary knowledge of the students regardless of the captions.

While Bird and Williams (2002) experiments led to the conclusion that subtitling can improve the learning of novel words, it seems that a crucial factor in the effectiveness of subtitling as a language teaching tool is repetition. Koolstra and Beentjes (1999) claimed that for learning vocabulary from subtitled movies, students have to watch them with high frequency. It can be assumed that subtitled movies could have an effect on vocabulary recognition if learners watch the movie more than once. Viewing the movie twice or more may help students recognize vocabulary and they may learn new expressions and idioms (Etemadi, 2012). 
In Garnier's empirical study, the relationship between repetition and word acquisition/retention was not straightforward, and was probably overshadowed by word-based (e.g. word class) and affective (e.g. motivation) factors (Garnier, 2014). Nevertheless, as learners seem to enjoy watching subtitled films anyway, enough vocabulary acquisition accrues from one or two viewings to recommend this activity as a useful supplement to formal instruction.

\section{Conflicts of Interest}

The author declares no conflicts of interest regarding the publication of this paper.

\section{References}

Aydin Yildiz, T. (2017). The Effect of Videos with Subtitles on Vocabulary Learning of EFL Learners. International Journal of Humanities and Social Science, 7, 125-130.

Baird, K., \& Redmond, M. (2004). The Use of Authentic Materials in the K-12 French Program. Winston-Salem, NC: Wake Forest University, Department of Education.

Baltova, I. (2006). Multisensory Language Teaching in a Multidimensional Curriculum: The Use of Authentic Bimodal Video in Core French. The Canadian Modern Language Review, 56, 32-48.

Beatty, K. (2015). Language, Task and Situation: Authenticity in the Classroom. Journal of Language and Education, 1, 27-37. https://doi.org/10.17323/2411-7390-2015-1-1-27-37

Berardo, S. A. (2006). The Use of Authentic Materials in the Teaching of Reading. The Reading Matrix, 6, 60-69.

Bird, S. A., \& Williams, J. N. (2002). The Effect of Bimodal Input on Implicit and Explicit Memory: An Investigation into the Benefits of Within-Language Subtitling. Applied Psycholinguistics, 23, 509-533. https://doi.org/10.1017/S0142716402004022

Borras, I., \& Lafayette, R. G. (1994). Effects of Multimedia Courseware Subtitling on the Speaking Performance of College Students of French. The Modern Language Journal, $78,66-75$

Breen, M. (1985). Authenticity in the Language Classroom. Applied Linguistics, 6, 60-70. https://doi.org/10.1093/applin/6.1.60

Danan, M. (2006). Reversed Subtitling and Dual Coding Theory: New Directions for Foreign Language Instruction. Language Learning, 42, 497-527.

https://doi.org/10.1111/j.1467-1770.1992.tb01042.x

Etemadi, A. (2012). Effects of Bimodal Subtitling of English Movies on Content Comprehension and Vocabulary Recognition. International Journal of English Linguistics, 2, 239-248.

Fazilatfar, A. M., Ghorbani, S., \& Samavarchi, L. (2011). The Effect of Standard and Reversed Subtitling versus No Subtitling Mode on L2 Vocabulary Learning. The Journal of Teaching Language Skills, 30, 43-64.

Garnier, M. (2014). Intentional Vocabulary Learning from Watching DVDs with Subtitles: A Case Study of an “Average” Learner of French. International Journal of Research Studies in Language Learning, 3, 21-32.

Gorjian, B. (2014). The Effect of Movie Subtitling on Incidental Vocabulary Learning among EFL Learners. International Journal of Asian Social Science, 4, 1013-1026. 
Guariento, W., \& Morely, J. (2001). Text and Task Authenticity in the EFL Classroom. ELT Journal, 55, 347-353. https://doi.org/10.1093/elt/55.4.347

Guichon, N., \& McLornan, S. (2008). The Effects of Multimodality on L2 Learners: Implications for CALL Resource Design. System, 36, 85-93.

https://doi.org/10.1016/j.system.2007.11.005

Harris, C., \& Marx, R. (2009). Authentic Tasks. The Gale Group, Inc. http://www.education.com/reference/article/authentic-tasks

Hedge, T. (2000). Teaching and Learning in the Language Classroom. Oxford: OUP.

Karakaş, A., \& Sariçoban, A. (2012). The Impact of Watching Subtitled Animated Cartoons on Incidental Vocabulary Learning of ELT Students. Teaching English with Technology, 12, 3-15.

Katchen, J., Fox, T., Lin, L. Y., \& Chun, V. (2001). Developments in Digital Video. In Third Pan-Asian Conference "2001: A Language Odyssey". Kuala Lumpur.

Kilickaya, F. (2004). Authentic Materials and Culture Content in EFL Classrooms. The Internet ELT Journal, 10.

Kim, D. (2000). A Qualitative Approach to the Authenticity in the Foreign Language Classroom: A Study of University Students Learning English in Korea. Texas Papers in Foreign Language Education, 5, 189-205.

Koolstra, C. M., \& Beentjes, J. W. J. (1999). Children's Vocabulary Acquisition in a Foreign Language through Watching Subtitled Television Programs at Home. Educational Technology Research and Development, 47, 51-60. https://doi.org/10.1007/BF02299476 http://www.springerlink.com/content/7951541774721423

Kusumarasdyati (2005). Subtitled Movie DVDs in Foreign Language Classes. Monash University. https://www.aare.edu.au/data/publications/2006/kus06105.pdf

Lee, W. Y.-c. (1995). Authenticity Revisited: Text Authenticity and Learner Authenticity. ELT Journal, 49, 325-328. https://doi.org/10.1093/elt/49.4.323

Martinez, A. G. (2002). Authentic Materials: An Overview. Free Resources for Teachers and Students of English. Karen's Linguistics Issues, 1-7.

Mcknight, A. (1995). Pragmatics and TESOL: Using Authentic Language Data. In Biennial Meeting of the MELTA International Conference in Innovations in Approaches to the Teaching and Learning of English. Kuala Lumpur.

McNeill, A. (1994). What Makes Authentic Materials Different? The Case of English Language Materials for Educational Television. In Annual International Language in Education Conference.

Miller, L. (2003). Developing Listening Skills with Authentic Materials. ESL Magazine, 6, 16-19.

Miller, M. (2005). Improving Aural Comprehension Skills in EFL, Using Authentic Materials: An Experiment with University Students in Nigata, Japan. Master's Thesis, University of Surrey.

Nunan, D. (1999). Second Language Teaching and Learning. Boston: Heinle and Heinle Publishers.

Perkins, D. N. (1993). Teaching for Understanding. American Educator, 17, 28-35.

Stevens, V. (1989). A Direction for Call: From Behaviorist to Humanistic Courseware. In M. Pennington (Ed.), Teaching Languages with Computers: The State of the Art (31-43). La Jolla, CA: Athelstan.

Taylor, D. (1994). Inauthentic Authenticity or Authentic in authenticity? The Electronic Journal for English as a Second Language, 1, 1-12. 
Underwood, J. (1990). Research in Hypertext: Desiderata. Computer Assisted English Language. Learning Journal, 1, 33-36.

Wong, V., Kwok, P., \& Choi, N. (1995). The Use of Authentic Materials at Tertiary Level. EFL Journal, 49, 318-322. https://doi.org/10.1093/elt/49.4.318

Yüksel, D., \& Tanriverdi, B. (2009). Effects of Watching Captioned Movie Clip on Vocabulary Development of EFL Learners. The Turkish Online Journal of Educational Technology, 8, 48-54.

Zanon, N. T. (2006). Using Subtitles to Enhance Foreign Language Learning. Porta Linguarum, 6, 41-52.

Zanon, N. T. (2007). Learning Vocabulary through Authentic Video and Subtitles. Tesol-Spain Newsletter, 31, 5-8.

Zarei, A. A. (2009). The Effect of Bimodal, Standard, and Reversed Subtitling on L2 Vocabulary Recognition and Recall. Pazhuhesh-e Zabanha-ye Khareji, No. 49, 65-85. 